ISSN (print): 1698-6180. ISSN (online): 1886-7995

www.ucm.es/info/estratig/journal.htm

Journal of Iberian Geology 38 (1) 2012: 161-174

http://dx.doi.org/10.5209/rev_JIGE.2012.v38.n1.39211

\title{
Recent and active tectonics in the western part of the Betic Cordillera
}

\section{Tectónica reciente y activa en la parte occidental de la Cordillera Bética}

\author{
A. Ruiz-Constán*1, A. Pedrera², J. Galindo-Zaldivar ${ }^{3}$, D. Stich $^{4}$, J. Morales $^{4}$ \\ ${ }^{1}$ Géosciences Montpellier, Université Montpellier 2-CNRS, Montpellier, France \\ ruiz@gm.univ-montp2.fr \\ ${ }_{2}^{2}$ Instituto Geológico y Minero de España, Madrid, Spain \\ a.pedrera@igme.es \\ ${ }^{3}$ Dpto. de Geodinámica, Universidad de Granada, Instituto Andaluz de Ciencias de la Tierra, CSIC- UGR, Granada, Spain \\ jgalindo@ugr.es \\ ${ }^{4}$ Instituto Andaluz de Geofisica, Universidad de Granada, Granada, Spain \\ daniel@iag.ugr.es; morales@ugr.es \\ *corresponding author
}

Received: 30/06/2011 / Accepted: 20/03/2012

\begin{abstract}
Based on new seismological and recent faulting data, we analyze five main sectors in the western part of the Betic Cordillera from an active tectonic perspective: i. The northwestern frontal sector of the cordillera, including the Morón de la Frontera area, with shallow ( $<15 \mathrm{~km}$ depth) seismogenic active NE-SW reverse and strike-slip faults that do not reach the surface. ii. The Teba area, in the External Zones, which is deformed by sparse N-S to NW-SE normal faults with associated wedges of Quaternary sediments and active strike-slip faults at intermediate crustal levels. iii. The Ronda Basin, representing the major Late Miocene intramontane basin of the western Betic Cordillera, is mainly deformed by NNE-SSW and WNW-ESE folds and locally by NW-SE normal faults. iv. The internal part of the orogen, which is characterized by shallow $(<40 \mathrm{~km})$ and intermediate ( 40 to $120 \mathrm{~km}$ depth) seismicity beneath Málaga and the Alborán Sea, ENE-WSW folding, relief uplift, river incision and scarce active faults with surface expression. v. The Spanish Atlantic coast, which coincides with the western end of the Betic orogen, where Pliocene to Quaternary shallowmarine sedimentary rocks are deformed by meso-scale NW-SE oriented normal faults and few ENE-WSW reverse faults. These data support the recent tectonic activity of the western Betic Cordillera determined by the NW-SE Eurasian-African convergence with variable features from the mountain front, characterized by shallow deformations, up to the Internal Zones that mainly undergo uplift and intermediate seismicity.
\end{abstract}

Keywords: active tectonics, Betic Cordillera, seismicity, stress, paleostress 


\section{Resumen}

Se han analizado, basándonos en nuevos datos sismológicos y de deformación reciente, cinco sectores de la Cordillera Bética occidental desde la perspectiva de la tectónica reciente: i. El sector frontal noroccidental de la cordillera, que incluye el área de Morón de la Frontera, con fallas sismogénicas superficiales $(<15 \mathrm{~km}$ de profundidad) de dirección NE-SO inversas y de salto en dirección, que no continúan hasta superficie. ii. El área de Teba, en las Zonas Externas, está deformada por escasas fallas de salto en dirección a niveles intermedios de la corteza y fallas normales de orientación N-S a NO-SE que cortan cuñas sedimentarias cuaternarias. iii. La Cuenca de Ronda, que representa la mayor cuenca intramontañosa de la Cordillera Bética occidental, está principalmente deformada por pliegues NNE-SSO y ONO-ESE y localmente por fallas normales de dirección NO-SE. iv. La parte interna del orógeno está caracterizada por sismicidad superficial $(<40 \mathrm{~km})$ e intermedia (40 a $120 \mathrm{~km}$ de profundidad) bajo Málaga y el Mar de Alborán, pliegues ENE-WSW, elevación del relieve, incisión fluvial y escasas fallas activas con expresión superficial. v. La costa Atlántica española, que coincide con la terminación occidental del orógeno Bético, donde las rocas sedimentarias marinas poco profundas del Plio-Cuaternario están deformadas por fallas normales NO-SE y algunas fallas inversas de orientación ENE-OSO. Todos estos datos revelan la actividad tectónica reciente de la Cordillera Bética occidental determinada por la convergencia NO-SE entre Eurasia y África, con variables características desde el frente montañoso, caracterizado por deformación superficial, hasta las Zonas Internas que muestran sismicidad intermedia y levantamiento.

Palabras clave: tectónica activa, Cordillera Bética, sismicidad, esfuerzo, paleoesfuerzo.

\section{Introduction}

The Betic Cordillera (Fig. 1a), located in the southern part of Spain, is a region of high seismic activity within the Iberian Peninsula. Most earthquakes are of low-tomoderate magnitude $(\mathrm{M}<5.5)$ and usually occur in the shallow brittle crust, with the exception of two localized areas of intermediate $(40-120 \mathrm{~km})$ and deep $(>620 \mathrm{~km})$ seismicity (Buforn et al., 1991). In the central and eastern sectors of the cordillera, seismicity and the associated seismic hazard have been widely studied and respectively related to NW-SE to WNW-ESE high-angle normal faults (Sanz de Galdeano et al., 1995; Alfaro et al., 2007) and NNE-SSW to NE-SW left-lateral segmented faults (Martinez Diaz, 2002; Masana et al., 2004), respectively. However, the western sector has been traditionally less known due to the scarcity and quality of the outcrops, the complex geological structure, and the lower frequency and magnitude of the seismic events. Seismic hazard at the western Betic Cordillera could be denoted as low to moderate.

The study of the potential seismic sources and their kinematics is of great interest in an area where historical consequences of seismic activity have been recorded. Repeated archeoseismic damaging events with intensity $\geq$ IX MSK were reported in the Roman city of Baelo Claudia around AD 40-60 and AD 260-290 (Goy et al., 1994; Silva et al., 2009). Historical earthquakes with maximum intensities of IX have been reported in the Guadalquivir Basin in 1504, with major effects in the city of Carmona (Gentil and de Justo, 1983; Martínez Solares and Mezcua, 2002), and in 1680 NW of Málaga (Muñoz and Udias, 1988). Most widespread historical damage, including a tsunami, was caused in the Cadiz Bay by the 1755 Lisbon earthquake, with an estimated magnitude of 8.5-8.7 and
EMS intensities between IV and VIII in the studied area (Martínez Solares and López Arroyo, 2004) but whose epicenter was located at the Cape of San Vicente, outside the study area.

Despite the aforementioned limitations, integration of brittle microtectonic and seismicity data in several key sectors of the western Betic Cordillera provide valuable information to clarify their heterogeneous behaviour. This study compiles and integrates new results, together with available recent tectonic data, to improve the characterization of recent paleostresses and present-day stresses in the northern branch of the Gibraltar Arc and better determine the main tectonic features of active sectors.

\section{Geological setting}

The Gibraltar Arc (Fig. 1a), formed by the junction between the Betic and Rif Cordilleras, constitutes the westernmost end of the Mediterranean Alpine Chain at the boundary between the Atlantic Ocean and the Mediterranean Sea. The present day relief of the Betic Cordillera has been formed by the interaction of Eurasia-Africa convergence together with the westward emplacement of the Internal Zones (Dewey et al., 1989; Rosenbaum et al., 2002), mainly composed of HP-LT metamorphic rocks (Gómez-Pugnaire and Fernández-Soler, 1987; Goffé et al., 1989). This emplacement provoked the thrust-andfold belt structure of the sediments deposited over the Iberian passive margin, the External Zones, during the Early-Middle Miocene (Sanz de Galdeano, 1990; Sanz de Galdeano and Vera, 1992). During this stage, the frontal disorganization of the External zones (olistostromic units) and the folding and thrusting of Cretaceous to Lower Miocene rocks of the Flysch units, located in between the External and the Internal Zones, ocurred (Luján 


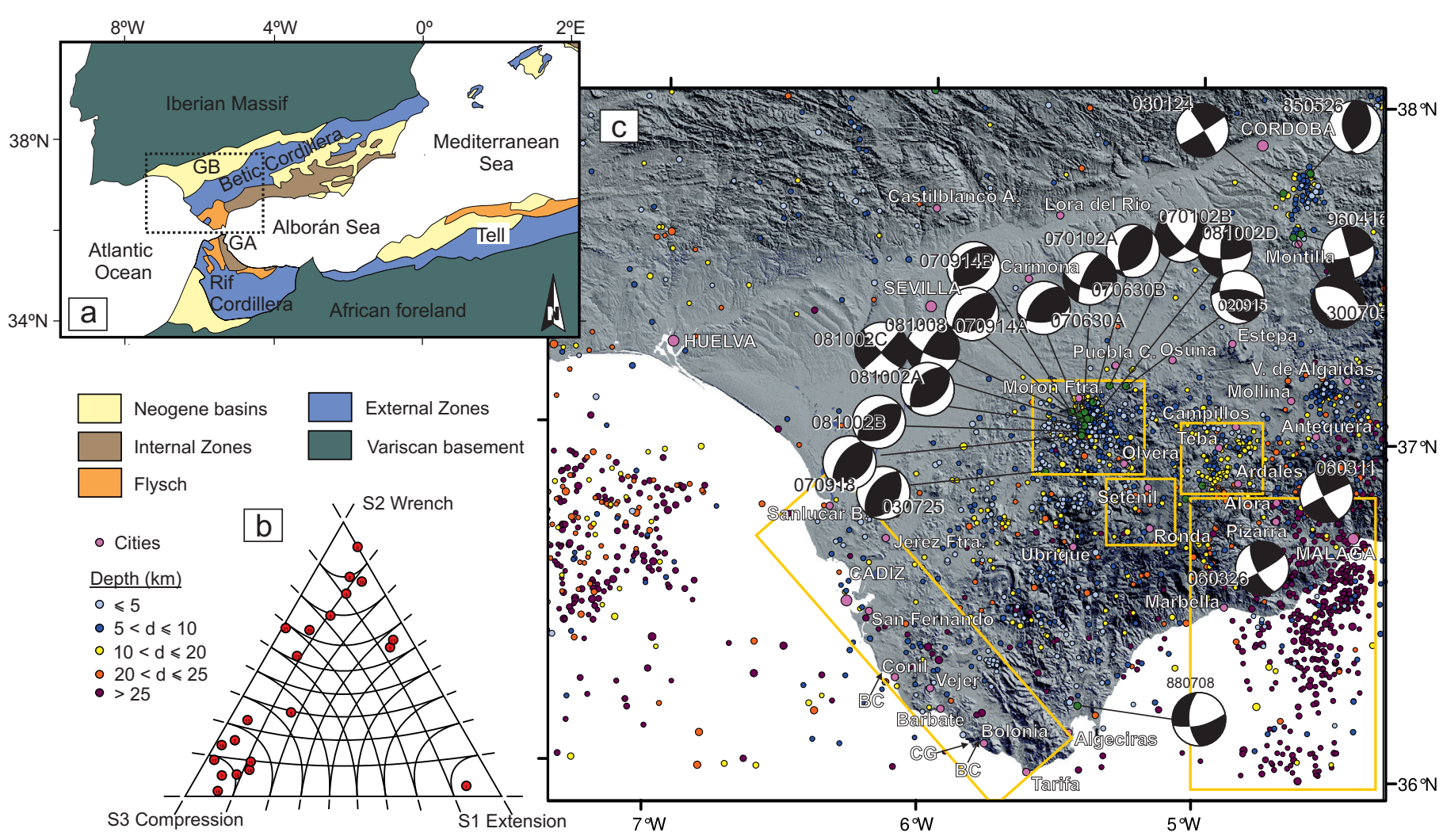

Fig. 1.- a) Geological map of the western Mediterranean; b) Frohlich diagram representing the faulting style of the earthquake focal mechanisms (Frohlich and Apperson, 1992; Célérier, 2012: FSA software 33.8 version); c) Seismicity distribution (IGN database; http://www.ign. es) and earthquake focal mechanism solutions in the western Betic Cordillera (Buforn et al., 1995; Mezcua and Rueda, 1997; Stich et al., 2003, 2006 and 2010; Batlló et al., 2010). Stereographic projection, lower hemisphere, compression in black CR: Cabo de Roche; CG: Cabo de Gracia; BC: Baelo Claudia.

Fig. 1.- a) Mapa geológico del Mediterráneo occidental; b) Diagrama de Frohlich de estilo de fracturación de los mecanismos focales (Frohlich y Apperson, 1992; Célérier, 2012: FSA software versión 33.8); c) Distribución de la sismicidad (base de datos IGN; http://www.ign.es) y mecanismos focales en la Cordillera Bética occidental (Buforn et al., 1995; Mezcua y Rueda, 1997; Stich et al., 2003, 2006 y 2010; Batlló et al., 2010). Proyección estereográfica, hemisferio inferior, compresión en negro. CR: Cabo de Roche; CG: Cabo de Gracia; BC: Baelo Claudia.

et al., 2003). Simultaneously, Lower to Middle Miocene extension was recorded at the sedimentary sequence of the Alborán basin (Chalouan and Michard, 2004) and at the metamorphic rocks of the Internal Zones (Aldaya et al., 1984; García-Dueñas et al., 1992; Platt and Vissers, 1989). Since the Late Tortonian, the main active processes have been volcanic activity, relief uplift, progressive individualization of intramontane sedimentary basins, and development of the Guadalquivir foreland basin due to the flexure of the Variscan Basement below the Betic Cordillera (Maury et al., 2000; García-Castellanos et al., 2002; Serrano et al., 2002; Sanz de Galdeano and Alfaro, 2004). The surface expression of recent and active tectonic structures is highly variable along the Betic Cordillera. The relief of the central and eastern sectors is mainly determined by E-W to ENE-WSW kilometer-size folds that deform up to Holocene sediments of the Alborán Sea (Galindo-Zaldívar et al., 2003; Marín-Lechado et al., 2006). These folds also interact with NW-SE to WNW-ESE high-angle normal faults (Sanz de Galdeano et al., 1995; Alfaro et al., 2007) and, in the easternmost sector, with large NNE-SSW to NE-SW left-lateral segmented faults (Gracia et al., 2008) that deform Quaternary sediments and have related low to moderate seismicity (Martínez Díaz, 2002; Masana et al., 2004; Stich et al., 2003, 2006). In the western sector, west of Málaga, recent tectonic activity is not as evident and practically no Quaternary faults could be observed at surface. However, the area is affected by recent uplift and river incision (Schoorl and Veldkamp, 2003; Sanz de Galdeano and Alfaro, 2004; Zazo et al., 1999, 2003) and active folding and fault activity has been reported at Sierra de Cártama and the Málaga Basin, mainly based on gravity data and drainage pattern analysis (Capote et al., 2002; Insua Arévalo et al., 2004; Insua Arévalo, 2008). The first neotectonic study performed in the area (Benkhelil, 

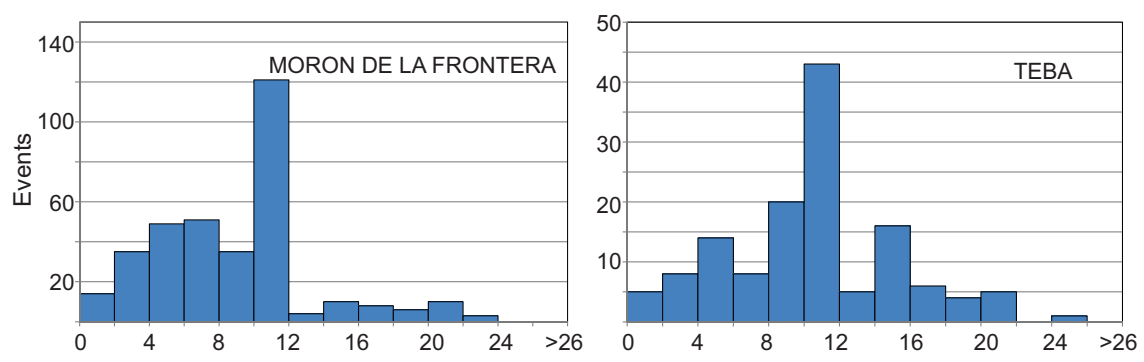

Fig. 2.- Frequency histogram of the hypocenters depth for shallow earthquakes in four sectors of the western Betic Cordillera.

Fig. 2.- Histograma de frecuencias de profundidad hipocentral de sismos superficiales en cuatro sectores de la Cordillera Bética occidental.
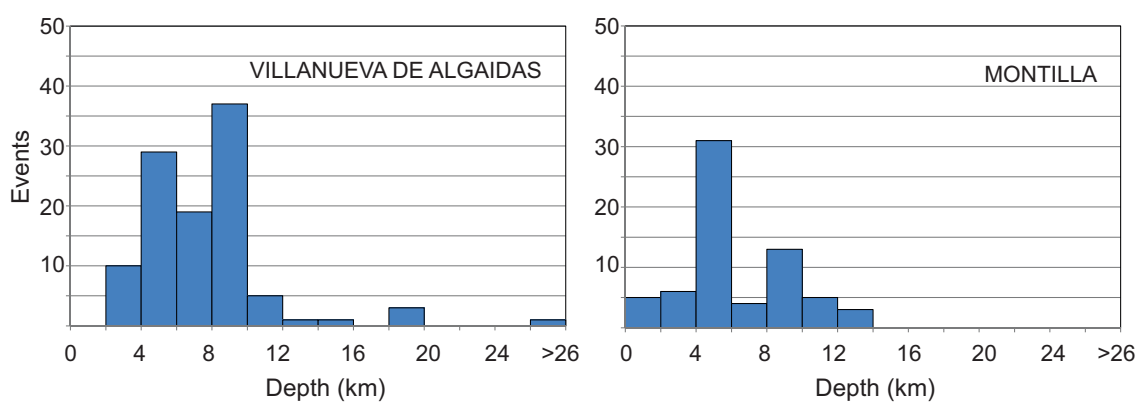

1976) revealed the existence of Quaternary NE-SW oriented left-lateral and NW-SE right-lateral faults. In a later detailed study of the Bolonia area, SE of Vejer, Silva et al. (2006) compiled a neotectonic map and defined the NE-SW Cabo de Gracia strike-slip fault as the main active fault in this sector, with an estimated activity younger than 128 ka. Northwards, in the San Fernando Sector, Upper Pleistocene beach deposits are affected by open joints filled by calcretes dated as $19.9 \mathrm{ka}$ (Gracia et al., 2008). Paleostress analysis of microtectonic structures affecting several outcrops of Upper Miocene to Quaternary sediments were also analyzed by Camacho et al. (1999), showing that most common brittle structures are NW-SE and NE-SW high-angle faults with oblique slip. At a frontal position, deformation and shallow seismicity reveal present-day activity of the mountain front in the Morón de la Frontera area (Ruiz-Constán et al., 2009). A recent compilation of Plio-Quaternary slip data, together with moment tensor solutions and borehole breakout measurements, reveal a NW-SE $\mathrm{SH}_{\max }$ trajectory in the mountain front that deflects to NNW-SSE at the Gibraltar Strait area (Pedrera et al., 2011).

\section{Seismicity distribution}

Between the Cape San Vincent area and Algeria, deformation along the Eurasia-Africa plate boundary zone is accommodated over a wide area with distributed seismicity, showing a complex pattern of GPS velocities, as well as heterogeneous earthquake focal mechanisms and stress patterns (e.g. Morel and Meghraoui, 1996; Buforn et al., 2004; Stich et al., 2006; Serpelloni et al., 2007; De Vicente et al., 2008; Pérouse et al., 2010). This area contrasts with more concentrated and homogeneous plate boundary deformation further east, showing mainly NWNNW directed thrusting events at the north Algerian margin, and further west, showing mainly strike-slip faulting along the oceanic portion of the plate boundary (Grimison and Chen, 1986; Buforn et al., 1988). Along the Iberia-Maghreb sector, earthquakes are of low-to-moderate magnitude $(\mathrm{M}<5.5)$ and occur at shallow depth, except in two localized areas of intermediate (40-120 km) and deep $(>620 \mathrm{~km})$ seismicity around Malaga and Granada, respectively (Buforn et al., 1991; Morales et al., 1997) as well as subcrustal earthquakes $(<60 \mathrm{~km})$ in old oceanic lithosphere in the Atlantic (Stich et al., 2005; Geissler et al., 2010). Within the Betic Cordillera, faulting style changes from predominately strike-slip in the eastern part to normal faulting in the central Betics and to reverse and strike-slip faulting in the western Betics (Stich et al., 2010). Within the western Betics, seismicity is usually of lower magnitudes (rarely exceeding magnitude 4) and less frequent than in the eastern and central sectors.

Figure 1c shows the seismicity distribution from the Instituto Geográfico Nacional database for magnitudes greater than 2 between 1980 and 2011 (IGN database, http://www.ign.es). The patchy pattern of the epicenter map indicates that seismic catalogues in this low seismicity area are actually dominated by a few instrumentally recorded sequences, yet we assume that basic properties of the recorded seismicity, such as focal depth and faulting style, are representative for the study area. We selected four regions where the amount of shallow instrumental seismicity is highest to show frequency histograms for the distribution of hypocenters with depth. The most active region is located near the town of Morón 
de la Frontera, in the northwestern front of the cordillera. Seismicity in this area is mainly related to seismic swarms occurring between the end of 2006 and the end of 2009. The four largest events show magnitudes between 4 and 5. Seismicity is concentrated in the upper crust, above $12 \mathrm{~km}$ depth (Figs. 1 and 2). No earthquakes occur at depths greater than $24 \mathrm{~km}$. In the other selected areas, the amount of seismicity is significantly lower than in the Morón area (Fig. 2). To the east, in the Teba sector, two earthquakes of magnitude between 4 and 4.5 have been recorded, and seismicity is mostly concentrated between 8 and $12 \mathrm{~km}$ (Figs. 1c and 2). The most active periods in the region were 1996, 2006 and the first months of 2011. Further to the east, around Villanueva de Algaidas and Mollina, seismic activity is mainly related to a seismic crisis that took place in 1989 (Figs. 1c and 2). Faulting appears to be slightly shallower than in the former regions. Magnitude in this sector is generally lower than 3 , with only eight earthquakes comprised between 3 and 3.5. To the north, we include one sector located in the Guadalquivir basin near the town of Montilla, related to activity mainly during 1985 (Figs. 1c and 2). Although the amount of seismic activity is lower than in the other areas, a 5.1 earthquake and four events between 4 and 5 have been recorded. Again, estimates for the hypocentral depth indicate faulting within the upper crust (Fig. 2).

\section{Earthquake focal mechanisms}

Twenty-one shallow earthquake focal mechanism solutions are available for the study area (Fig. $1 \mathrm{~b}$ and Table 1). Eighteen solutions were obtained from the time domain moment tensor inversion of full waveform recordings at regional distances, and are included in the moment tensor catalogue of the Instituto Andaluz de Geofísica (Stich et al., 2003, 2006 and 2010). Most moment tensor solutions are for earthquakes since 2006, a period characterized by more frequent than average $\mathrm{M}>3.5$ earthquakes in this sector, as well as denser seismic broadband instrumentation than previous years. We also included in this analysis two earthquake focal mechanisms between Montilla and Córdoba calculated through the first motion of $\mathrm{P}$ waves (850526 and 960416; Buforn et al., 1995; Mezcua and Rueda, 1997) and one solution for the same area based on full waveform inversion of digitized historic seismograms of a magnitude 5.1 earthquake in 1930 (300705; Batlló et al., 2010).

The overall picture emerging from the shallow earthquake focal mechanisms, shown in Figure 1, is a predominance of strike-slip and reverse faulting, as well as a preferred NW-SE orientation of focal mechanism P-axes. However, there is a relevant level of heterogeneity, like the presence of strike-slip mechanisms with opposite

\begin{tabular}{|c|c|c|c|c|c|c|c|c|c|c|c|c|c|c|}
\hline $\begin{array}{c}\text { Date } \\
(\mathrm{yy} / \mathrm{mm} / \mathrm{dd})\end{array}$ & $\begin{array}{l}\text { Origin time } \\
\text { (hh:mm:ss) }\end{array}$ & $\begin{array}{c}\text { Latitude } \\
{\left[{ }^{\circ} \mathrm{N}\right]}\end{array}$ & $\begin{array}{c}\text { Longitude } \\
{\left[{ }^{\circ} \mathbf{E}\right]}\end{array}$ & $\begin{array}{c}\text { Depth } \\
{[\mathrm{km}]}\end{array}$ & $\begin{array}{c}\text { Seismic } \\
\text { moment }[\mathrm{Nm}]\end{array}$ & $\begin{array}{l}\text { Magni- } \\
\text { tude } M_{w}\end{array}$ & $\begin{array}{c}\text { Strike1 } \\
{\left[{ }^{\circ}\right]}\end{array}$ & $\begin{array}{c}\text { Dip1 } \\
{\left[{ }^{\circ}\right]}\end{array}$ & $\begin{array}{c}\text { Rake1 } \\
{\left[{ }^{\circ}\right]}\end{array}$ & $\begin{array}{c}\text { Strike2 } \\
{\left[{ }^{\circ}\right]}\end{array}$ & $\begin{array}{c}\text { Dip2 } \\
{\left[{ }^{\circ}\right]}\end{array}$ & $\begin{array}{c}\text { Rake2 } \\
{\left[{ }^{\circ}\right]}\end{array}$ & $\begin{array}{c}\text { CLVD } \\
{[\%]}\end{array}$ & $\begin{array}{c}\text { Refer- } \\
\text { ence }\end{array}$ \\
\hline 300705 & - & 37.56 & -4.65 & 16 & $5.48 \cdot 10^{16}$ & 5.1 & 123 & 39 & -86 & 298 & 51 & -93 & 2 & 1 \\
\hline 850526 & $18: 05: 10$ & 37.80 & -4.60 & 5 & - & $5.1 \mathrm{Mb}$ & 174 & 51 & 70 & 25 & 43 & 114 & - & 2 \\
\hline 880708 & $23: 31: 11$ & 36.21 & -5.42 & 8 & $0.17 \cdot 10^{16}$ & 4.1 & 178 & 61 & -159 & 78 & 72 & -31 & 19 & 3 \\
\hline 960416 & $22: 44$ & 37.61 & -4.66 & 8 & - & $4.3 \mathrm{Mb}$ & 75 & 76 & -179 & 345 & 89 & -14 & - & 4 \\
\hline 020915 & $20: 54: 19$ & 37.16 & -5.27 & 4 & $1.42 \cdot 10^{15}$ & 4.1 & 273 & 68 & 58 & 152 & 38 & 143 & 5 & 5 \\
\hline 030124 & $20: 35: 00$ & 37.74 & -4.70 & 12 & $2.08 \cdot 10^{15}$ & 4.2 & 58 & 86 & -176 & 327 & 86 & -3 & 14 & 5 \\
\hline 030725 & $03: 37: 55$ & 36.90 & -5.56 & 6 & $1.91 \cdot 10^{14}$ & 3.5 & 29 & 40 & 82 & 219 & 51 & 96 & 6 & 5 \\
\hline 060311 & $13: 43: 07$ & 36.87 & -4.98 & 22 & $6.92 \cdot 10^{14}$ & 3.9 & 243 & 88 & -170 & 152 & 80 & -2 & 1 & 6 \\
\hline 060326 & $18: 15: 40$ & 36.83 & -5.04 & 14 & $3.47 \cdot 10^{14}$ & 3.7 & 151 & 70 & 5 & 60 & 85 & 160 & 10 & 6 \\
\hline 070102A & $12: 19: 26$ & 37.11 & -5.39 & 10 & $2.98 \cdot 10^{14}$ & 3.6 & 135 & 79 & -174 & 44 & 84 & -10 & 19 & 6 \\
\hline 070102B & $15: 00: 47$ & 37.16 & -5.33 & 14 & $3.24 \cdot 10^{14}$ & 3.6 & 136 & 71 & -152 & 37 & 64 & -21 & 22 & 6 \\
\hline 070630A & $03: 53: 45$ & 37.07 & -5.44 & 8 & $3.88 \cdot 10^{15}$ & 4.4 & 81 & 45 & 123 & 218 & 53 & 61 & 6 & 6 \\
\hline 070630B & $11: 29: 35$ & 37.08 & -5.42 & 8 & $3.06 \cdot 10^{14}$ & 3.6 & 103 & 58 & 158 & 205 & 71 & 34 & 13 & 6 \\
\hline 070918 & $23.20: 42$ & 37.01 & -5.43 & 8 & $8.57 \cdot 10^{14}$ & 3.9 & 52 & 34 & 103 & 217 & 57 & 82 & 3 & 6 \\
\hline 070914A & $03: 45: 06$ & 37.08 & -5.47 & 12 & $2.39 \cdot 10^{15}$ & 3.6 & 65 & 35 & 107 & 224 & 56 & 78 & 15 & 6 \\
\hline 070914B & $03: 46: 49$ & 37.08 & -5.47 & 8 & $2.67 \cdot 10^{15}$ & 3.6 & 51 & 54 & 97 & 220 & 36 & 81 & 3 & 6 \\
\hline 081002A & $04: 02: 53$ & 37.04 & -5.42 & 4 & $6.89 \cdot 10^{15}$ & 4.5 & 54 & 44 & 103 & 216 & 47 & 78 & 1 & 6 \\
\hline 081002B & 04:05:06 & 37.02 & -5.43 & 12 & $9.17 \cdot 10^{14}$ & 3.9 & 54 & 39 & 92 & 232 & 51 & 88 & 13 & 6 \\
\hline $081002 \mathrm{C}$ & $05: 14: 19$ & 37.06 & -5.43 & 6 & $1.19 \cdot 10^{14}$ & 3.4 & 44 & 45 & 109 & 198 & 48 & 72 & 4 & 6 \\
\hline 081002D & 09:22:14 & 37.06 & -5.40 & 16 & $7.66 \cdot 10^{13}$ & 3.2 & 87 & 66 & 166 & 183 & 77 & 25 & 7 & 6 \\
\hline 081008 & $16: 04: 47$ & 37.06 & -5.41 & 12 & $2.11 \cdot 10^{14}$ & 3.5 & 211 & 69 & 24 & 111 & 68 & 157 & 5 & 6 \\
\hline
\end{tabular}

Table 1.- Solutions for shallow earthquake focal mechanisms represented in Figure 1. The reference's article corresponds to: Batlló et al., 2010 [1]; Buforn et al., 1995 [2]; Stich et al., 2003[3]; Mezcua and Rueda, 1997 [4]; Stich et al., 2006 [5], 2010 [6]). Dashes indicate data not available.

Tabla 1.- Mecanismos focales de terremotos representados en la Figura 1. La referencia de los artículos se corresponde con: Batlló et al., 2010 [1]; Buforn et al., 1995 [2]; Stich et al., 2003[3]; Mezcua and Rueda, 1997 [4]; Stich et al., 2006 [5], 2010 [6]. Los guiones indican datos no disponibles. 


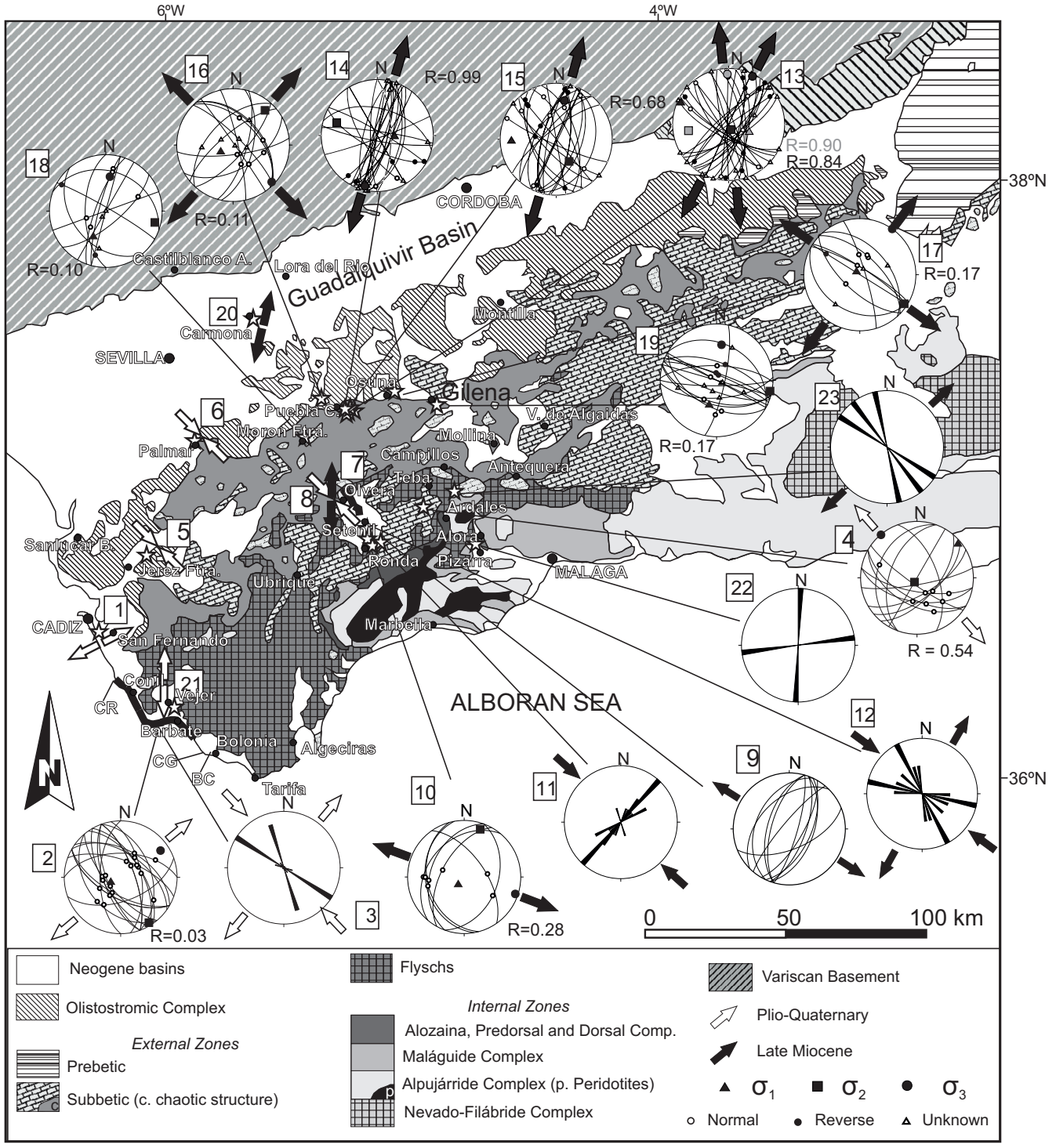

Fig. 3.- Microtectonic data in Upper Miocene to Quaternary rocks (Table 2); stereographic projection, lower hemisphere. CR: Cabo de Roche; CG: Cabo de Gracia; BC: Baelo Claudia.

Fig. 3.- Datos microtectónicos en rocas del Mioceno Superior al Cuaternario (Tabla 2); proyección estereográfica, hemisferio inferior. CR: Cabo de Roche; CG: Cabo de Gracia; BC: Baelo Claudia. kinematics. Plotting faulting style into Frohlich diagrams (Fig. 1b; Frohlich and Apperson, 1992; Célérier, 2012) confirms that most solutions correspond to reverse and strike slip faulting. Only one mechanism is of pure extension. The geographical distribution of available focal mechanisms is very heterogeneous, following the pattern of recent seismicity. Fourteen of them are concentrated at the mountain front, near Morón de la Frontera, and the faulting style ranges from pure reverse to pure strike-slip. Reverse faults show NE-SW nodal planes and hypocenter depths of 4-12 km. Depths of strike-slip solutions at the mountain front, with mainly $\sim \mathrm{NW}-\mathrm{SE}$ and $\sim \mathrm{SW}-\mathrm{NE}$ striking nodal planes, vary between 4 and $16 \mathrm{~km}$. To the east, in the Teba sector, two similar earthquake focal mechanism solutions were determined (060311 and 060326 events). Both of them are strike-slip faults with NW-SE and NE-SW nodal planes and depths of 14 and $22 \mathrm{~km}$. To the north, four earthquake focal mechanisms are located along the Guadalquivir Basin, between Montilla and Cór- doba. The shallowest (850526) is a NNE-SSW reverse fault located at a depth of $5 \mathrm{~km}$. Between 8 and $12 \mathrm{~km}$ there are two similar strike-slip faults with NW-SE and NE-SW nodal planes (960416 and 030124). The deepest solution (300705) corresponds to the moment magnitude $\mathrm{Mw} 5.1$ earthquake that affected the town of Montilla in 1930 with an estimated epicentral intensity of VIII MSK (Kárník, 1969; Batlló et al., 2010) and is the largest event recorded instrumentally in the western Betics. The solution is a NW-SE normal fault located at $16 \mathrm{~km}$ depth, though depth resolution is low for this event. Finally, an oblique normal fault, with $\sim \mathrm{N}-\mathrm{S}$ and $\sim \mathrm{E}-\mathrm{W}$ nodal planes, is located onshore at the Gibraltar strait (880708).

The average stress tensor calculated from the focal mechanisms indicates a maximum NW-SE principal major stress, parallel to plate convergence, with a northwestward inclination of maximum stress, compatible with the activity of low-angle thrust faults (Ruiz-Constán et al., 2009; Pedrera et al., 2011). In addition, a high axial ra- 
tio value (as defined by Galindo-Zaldívar and GonzálezLodeiro, 1988; $\left.\mathrm{R}=\left(\sigma_{2}-\sigma_{3}\right) /\left(\sigma_{1}-\sigma_{3}\right)\right)$ may favour stress permutations between $\sigma_{2}$ and $\sigma_{1}$ and allow local NE-SW compression (indeed, observed for event 020915 in Table 1). However, the observed heterogeneity of faulting indicates that the average stress tensor may not accurately represent this complex study area, for which reason this work aims to provide a more specific characterization of individual areas.

\section{Recent brittle deformation and paleostress analysis}

We have divided the western Betic Cordillera into five different sectors for the analysis of recent brittle deformation (Fig. 3), depending on their geological setting. Analysis is focused on the sectors with recent sedimentary cover, allowing us to constrain the deformation age. Accordingly, palaeostress orientations were determined for the Middle-Late Miocene to the Quaternary through analysis of brittle meso- and micro-structures such as faults and joints, taking into account that in many cases more recent sediments do not crop out or are poorly deformed and make it impossible to differentiate phases. Stress inversion was accomplished using the Galindo-Zaldívar and González-Lodeiro (1988) Search Grid method. It is based on a systematic search on a grid pattern that allows for the determination of overprinted stress tensors, axis orientations and axial ratios (Fig. 3). All the new results are described in Table 2, together with previous paleostress inversions performed in the area (Camacho et al., 1999; Gracia et al., 2008; Ruiz-Constán et al., 2009; Pedrera et al., 2011).

\subsection{Morón de la Frontera Sector (Mountain front)}

Scarce outcrops record the present-day deformation at the northwestern mountain front of the Betic Cordillera due to several factors, including slow tectonic activity, the erodability of the sedimentary filling of the Guadalquivir basin, and the chaotic structure of the Olistostromic Complex. However, in contrast to the neighbouring sectors, this area is affected by very shallow seismicity (around $8 \mathrm{~km}$ depth), suggesting the presence of active tectonic structures (Ruiz-Constán et al., 2009). The present-day relief of the northwestern mountain front has a roughly NE-SW trend associated with the nucleation of NE-SW open folds. The development of these folds is linked to the present-day activity of NW-SE blind thrusts, indicated by seismic data (Stich et al., 2010), that deform the upper part of the crust without reaching the surface. Nevertheless, due to uncertainties in focal depth estimation, it could not be asserted if the seismogenic active thrusts are located in the upper part of the Variscan basement or just at its boundary with the Betic tectonic units.

Several paleostress stations located on Middle-Late Miocene marls and marly limestones cropping out in the surroundings of Morón de la Frontera and Puebla de Cazalla reveal high deformation at surface. The most important structures affecting the limit between the autochthonous Guadalquivir sediments and the Olistostromic Complex are mainly subvertical NNE-SSW and NW-SE strike-slip faults (Fig. 4a; stations 13-16 and 18). For the same age, stations located to the east, near Gilena and Osuna (stations 17 and 19), reveal the prevalence of WNWESE to NW-SE normal faults with an oblique slip. A well constrained nearly horizontal NNE-SSW extension was determined for stations 13 to 15 , oblate in shape in all. In addition, a secondary local paleostress with a N-S SH was determined at station 13 (Fig. 3). Stations 16 and 17 reveal radial extension with a subvertical $\sigma_{1}$ and low axial ratios. Finally, the paleostress determined for stations 18 and 19 shows prolate shapes and a $\sigma_{1}$ dipping $50-60^{\circ}$ toward the SSW.

In the westernmost part of the mountain front, near El Palmar (station 6), more recent sediments of the Late Pliocene are deformed by N-S to NE-SW normal faults with a strike-slip component and low dip toward the $\mathrm{W}$ and NW, respectively, that define a well constrained NW$\mathrm{SE} \mathrm{SH}_{\max }$ (Camacho et al., 1999). To the south, in the Jerez de la Frontera area (station 5), two sets of NW-SE and NE-SW high angle normal faults also determine a $\mathrm{NW}^{-S E ~ S H} \mathrm{~m}_{\text {max }}$ (Camacho et al., 1999). No reverse faults were observed at these outcrops. Finally, the only station located in the autochthonous Upper Miocene sandstones of the Guadalquivir basin, near Carmona (station 20), reveals the existence of NE-SW high angle strike-slip faults that determine well defined subhorizontal N-S extension (Camacho et al., 1999).

\subsection{Teba Sector (External Zones)}

Brittle deformation in Upper Miocene calcarenites cropping out in the area is scarce and constituted by a main set of NW-SE tensional joints (station 23). Recent mesoscale faults have only been identified at the boundaries of the ranges composed by Jurassic limestones in the Teba and Cañete la Real area. They generally show dips higher than $60^{\circ}$, oblique slip and transtensional right-lateral and left-lateral kinematics that vary depending on the fault plane orientations (Fig. 3, station 4). However, NESW normal faults are also frequent. Wedge-like deposits of Quaternary coarse-grained sediments that thicken towards the fault plane were observed in the hanging wall of one of these faults located near Cañete la Real (Fig. 


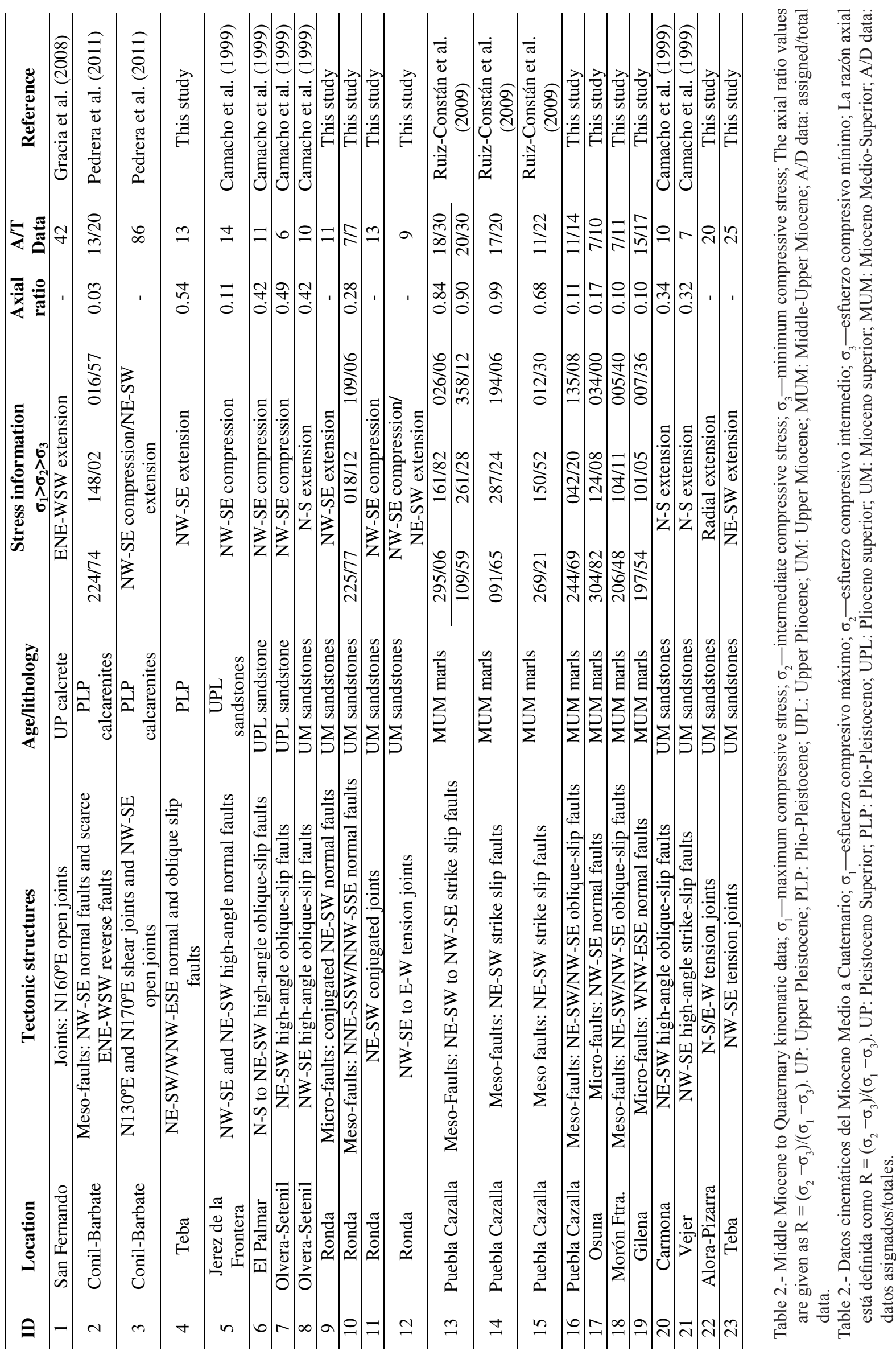




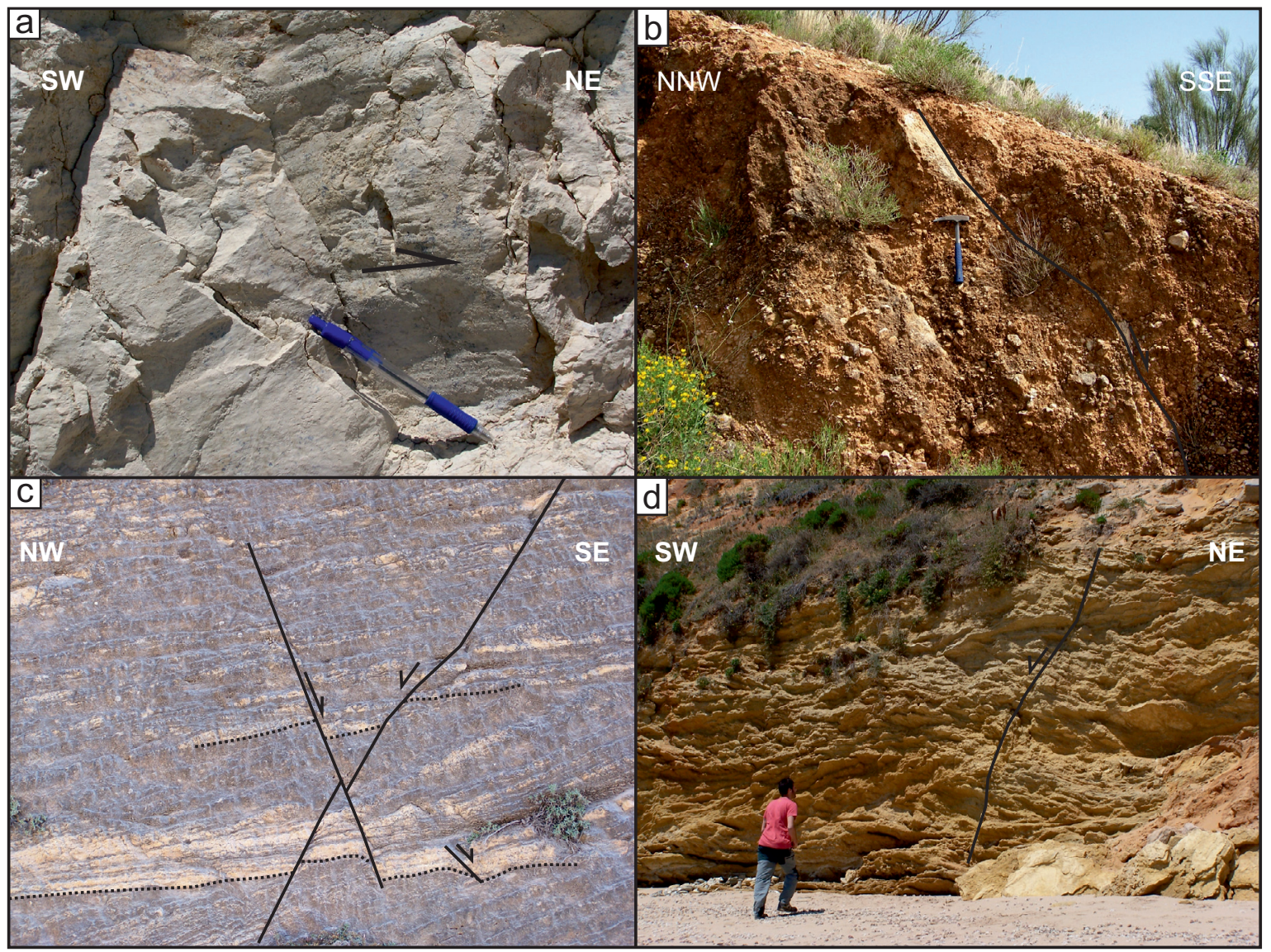

Fig. 4.- Field examples of different brittle structures that deform Middle-Late Miocene to Quaternary rocks. (a) Strike-slip striae in Middle-Late Miocene marls and Marly limestones at the Puebla de Cazalla sector; (b) WNW-ESE normal fault in a Quaternary wedge of sediments in the Teba sector; (c) NE-SW conjugated normal faults in Upper Miocene calcarenites of the Ronda Basin; and (d) NE-SW normal fault deforming Plio-Pleistocene calcarenites in the Cabo de Roche-Conil section.

Fig. 4.- Ejemplo de campo de estructuras frágiles que deforman rocas de edad Mioceno Medio-Superior a Cuaternario. (a) Estría de salto en dirección en margas y calizas margosas de edad Mioceno Medio-Superior en el sector de Puebla de Cazalla; (b) falla normal de dirección ONO-ESE en una cuña sedimentaria cuaternaria en el sector de Teba; (c) fallas normales conjugadas de dirección NE-SO en calcarenitas del Mioceno Superior en la Cuenca de Ronda; y (d) falla normal NE-SO que deforma calcarenitas Plio-Pleistocenas en la sección entre Cabo de Roche y Conil.

$4 b)$. It is a $\mathrm{N} 60^{\circ} \mathrm{E}$ normal fault $300 \mathrm{~m}$ in length dipping $65^{\circ}$ towards the SE. Traditionally, the development of colluvial wedges has been generally considered as evidence for earthquake related faulting (McCalpin 1996).

\subsection{Ronda Sector (Neogene Intramontane Basin)}

The Ronda Depression, the main intramontane basin of the western Betic Cordillera, is located at the contact between the External Zones and the Flysch unit. Its sedimentary infill is mainly constituted by Late Miocene conglomerates, marls and sandstones (Serrano, 1979; Rodríguez-Fernández, 1982). The boundaries of the basin are unconformities. Recent deformation consists predominantly of medium to large scale NNE-SSW and WNW-ESE folds (Crespo Blanc and Campos, 2001), while brittle deformation is scarce and localized (RuizConstán et al., 2008). The NE-SW and NNW-SSE mi- nor normal faults mainly deform Tortonian calcarenites and are mainly gathered in the southern part of the basin (Ruiz-Constán et al., 2008). Faults rarely show striation or other kinematic indicators; nevertheless, the conjugated fault sets and the displacement of reference surfaces suggest a normal component.

In the Ronda-Setenil section, the Upper Miocene sediments are mainly deformed by a metric set of conjugated NE-SW normal faults with centimetric displacement, dipping $45^{\circ}-80^{\circ}$ (stations 9 and 10; Figs. 3 and 4c). There are also two orthogonal NW-SE and NE-SW sets of vertical tension joints together with a joint spectra (Hancock, 1985) that includes tension and shear joints of other orientations (stations 11 and 12). Paleostress analysis of the micro- and meso- faults reveals N-S to NW-SE compression with low axial ratios (stations 9 and 10), whereas results of joint set analysis give a parallel direction of extension (stations 11 and 12). To the north, in the Setenil- 


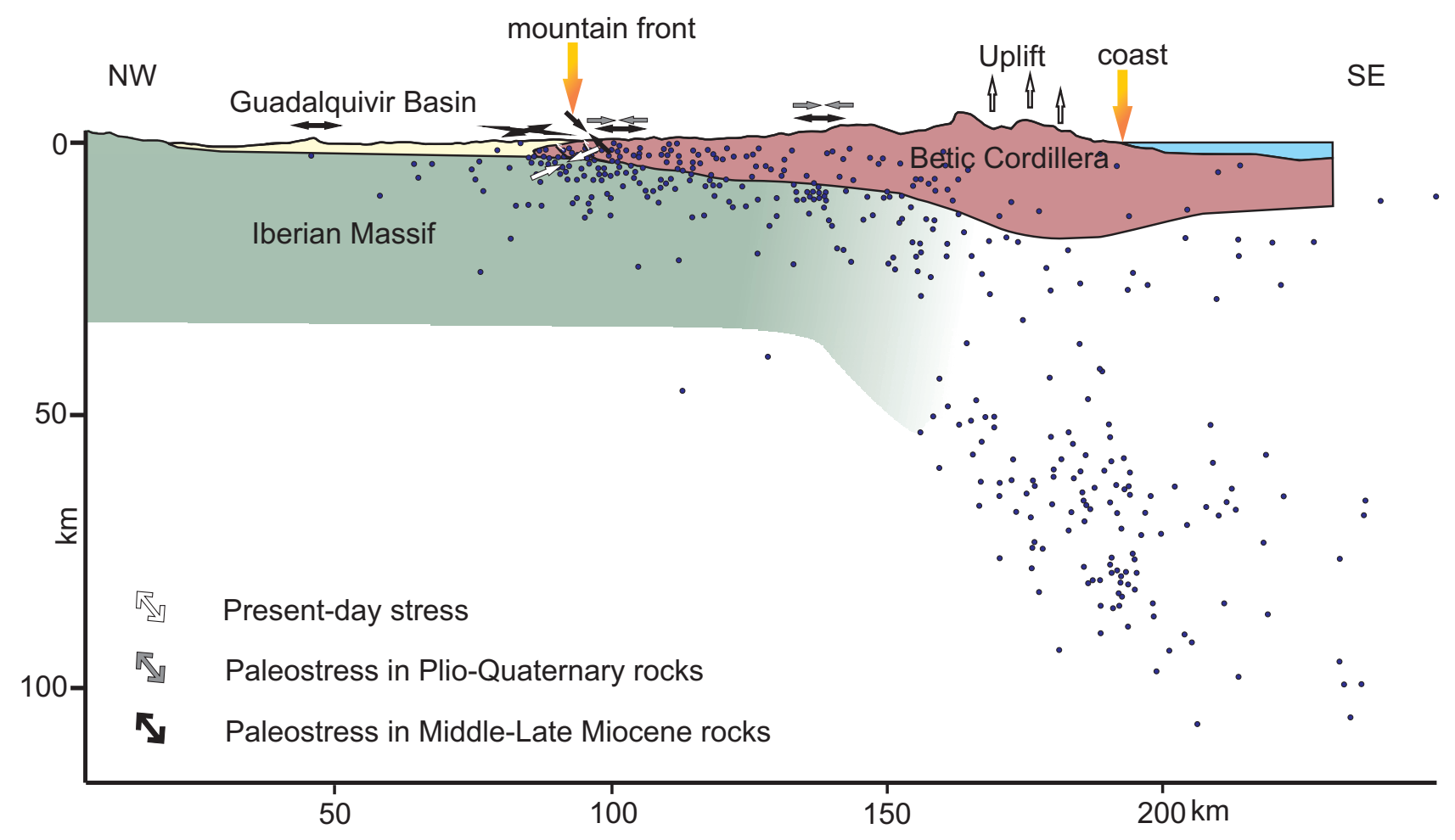

Fig. 5.- Tectonic sketch of the northwestern transect of the Betic Cordillera (modified from Morales et al., 1999; Ruiz-Constan et al., 2009 and 2011). The vertical scale of the topographic profile is multiplied by a factor of 2.

Fig. 5.- Esquema tectónico de la transversal noroccidental de la Cordillera Bética (modificado de Morales et al., 1999; Ruiz-Constan et al., 2009 and 2011). La escala vertical del perfil topográfico está multiplicada por un factor de 2.

Olvera section, Camacho et al. (1999) described two sets of faults. The first one (station 8 ) is constituted by NESW normal faults with a strike-slip component dipping towards the NW that cuts Upper Miocene rocks. The second one (station 7), deforming Pliocene-Quaternary sediments, is composed by high-angle NW-SE normal faults dipping towards the NE that define a NW-SE $\mathrm{SH}_{\max }$.

\subsection{Alborán coast sector (Internal Zones)}

Upper Tortonian calcarenites cropping out in the area of El Chorro ( $\mathrm{N}$ of Ardales), Alora and Pizarra, have undergone recent tectonic uplift and tilting. They are a reliable marker for estimating recent uplift rates because they were deposited in coastal or very shallow marine environments during the Tortonian and at Present they are located, from north to south, between 620 and 450 $\mathrm{m}$ a.s.1. Upper Tortonian shallow-water calcarenites were deposited on inner platforms at depths of less than $30 \mathrm{~m}$ (Braga et al., 2003) approximately in the time interval from 8.5 to $7.5 \mathrm{Ma}$. In addition, Pliocene marine deposits are now situated between 180 and $114 \mathrm{~m}$ a.s.l. Uplift rates in this sector have been estimated in $0.16-2.76 \mathrm{~mm} / \mathrm{a}$ during the Tortonian-Messinian, decreasing to $0.01-0.015$ $\mathrm{mm} / \mathrm{a}$ during the Pliocene, then increasing again to 0.04$0.1 \mathrm{~mm} / \mathrm{a}$ during the Pleistocene (Schoorl and Veldkamp, 2003). However, these rocks are scarcely deformed by faults. Two sets of orthogonal joints with N-S and E-W orientations were measured in the surroundings of Ardales (station 22). This setting determines the incision of the fluvial networks of the Alborán coast, with areas of very abrupt topography.

\subsection{Atlantic coast sector (westernmost orogen boundary)}

Brittle microtectonic data measured on Upper Miocene to Quaternary rocks cropping out in localized sections constitute the available long-term stress indicators in this area (Camacho et al., 1999; Silva et al., 2009; Pedrera et al., 2011). Station 1 (Gracia et al., 2008) points to ENE-WSW extension based on the existence of $\mathrm{N} 160^{\circ} \mathrm{E}$ tensional joints deforming an Upper Pleistocene calcrete near San Fernando. Pedrera et al. (2011) described brittle deformation affecting Pliocene and Quaternary shallow-marine sedimentary rocks in two sections of the Atlantic coast: the Roche Cape-Conil section and the Trafalgar Cape-Barbate section. The former section is strongly deformed by two sets of normal faults with 
NW-SE to WNW-ESE orientations, indistinctly dipping around $50^{\circ}-60^{\circ}$ to the NE or SW (station 2; Fig. 4d). These faults determine a subvertical maximum stress axis, and NE-SW subhorizontal extension. Some faults of the WNW-ESE set show a right-lateral component. Compressive structures are less frequent and are constituted by minor Upper Pliocene-Lower Pleistocene E-W to ENE-WSW reverse faults (Silva et al., 2009). In addition, NW-SE vertical open joints together with $\mathrm{N} 130^{\circ} \mathrm{E}$ and $\mathrm{N} 170^{\circ} \mathrm{E}$ conjugated shear joints deform the Upper Pliocene-Lower Pleistocene beach sediments (station 3; Pedrera et al., 2011) and indicates NE-SW extension and NW-SE compression. To the south, along the Trafalgar Cape-Barbate section, the same NW-SE to WNW-ESE sets of normal faults and joints highly deform the Tortonian and Messinian calcareous sandstones. The recent activity of these faults is well constrained because they broke up terraces that developed during the MIS $5 \mathrm{c}$ marine deposition $(\sim 105 \mathrm{ka})$. In the Vejer area, located between the two sections, NW-SE normal faults deform Upper Miocene sandstones and determine a well defined subhorizontal N-S extension (station 21; Camacho et al., 1999).

Despite variability, analysis of brittle deformation in the whole area reveals the activity of faults having a favorable orientation with respect to the NW-SE convergence between Eurasia and Africa. Most of the paleostresses calculated are compatible with this context, showing a prevailing NW-SE subhorizontal compression and orthogonal extension.

\section{Discussion}

Although there are no prominent active faults cropping out in the western Betic Cordillera, low to moderate earthquakes occur in this area regularly. Here we summarize deformation patterns, seismicity distribution and recent and present-day stresses, with discussion of their active tectonics and geodynamic implications.

The northwestern mountain front is probably one of the sectors of the western Betics with the greatest concentration of earthquakes during recent times (seismic series of Morón de la Frontera, Teba and Villanueva de Algaidas/ Mollina). Seismicity is associated with the activity of NESW blind thrusts and NW-SE transfer faults (Ruiz-Constán et al., 2009). These structures, identified by means of seismic data (Stich et al., 2010), deform the upper part of the crust without reaching the surface. In addition, errors in the foci determination of the earthquake focal mechanism solutions do not allow us to confirm whether the seismogenic active thrusts deform the upper part of the
Variscan basement or its contact with the Betic tectonic units. Although seismic activity is usually of low magnitude $(\mathrm{M}<5)$, it occurs at very shallow depths $(<12 \mathrm{~km})$ in an area with a widespread presence of thick plastic Triassic rocks mixed within the Olistostromic Unit that could favour seismic amplification effects.

This last unit, involving plastic Triassic rocks, extends toward the Gulf of Cadiz, where it formed the so-called Gulf of Cadiz Imbricate Wedge. Pliocene and Quaternary shallow-marine sedimentary rocks placed above this unit along the Atlantic coastal sector are deformed by small NW-SE to WNW-ESE normal faults, indistinctly dipping to the NE or SW (Pedrera et al., 2011; Camacho et al., 1999). The recent activity of these small faults is well constrained, since they broke up terraces dated as $~ 105$ ka (Zazo et al., 1999). Compressive structures are less frequent and constituted by minor E-W to ENE-WSW reverse faults (Silva et al., 2009). In contrast to the Moron de la Frontera mountain front, seismicity is very scarce in this sector of the Gibraltar Arc.

Recent NW-SE to N-S (and locally NE-SW) normal faults to normal-oblique faults together with kilometricscale open folds, generally ENE-WSW trending, are identified along the Internal Subbetics and Flysch units deforming previous Early Miocene folds-and-thrusts (e.g. Balanyá et al., 2007). Only local evidence of Quaternary activity has been detected near Cañete la Real, related to a $\mathrm{N} 60^{\circ} \mathrm{E}$ normal fault dipping $65^{\circ}$ towards the $\mathrm{SE}$ and measuring $300 \mathrm{~m}$ in length. In the eastern part of the study area, the infill of the Neogene Ronda Basin, located at the contact between the External Zones and the Flyschs, provides a good marker to constrain the timing of recent deformation. There, Upper Miocene sandstones are mainly deformed by medium to large scale NNESSW and WNW-ESE folds; meanwhile, brittle deformation is scarce, localized and generally of low intensity. NW-SE to NNW-SSE and local NE-SW normal faults deform the Upper Miocene rocks and, rarely, PlioceneQuaternary sediments (Camacho et al., 1999; Ruiz-Constán et al., 2008). Although the NW-SE trending normal faults and the ENE-WSW folds and reverse faults are favorably oriented for reactivation under present-day stress conditions, it is very difficult to correlate earthquakes to specific faults along the Internal Subbetics and Flysch fold-and-thrust belt.

Along the Internal Zones it is likewise problematic to correlate seismicity and tectonic structures. Seismicity is concentrated within the lower crust and the lithospheric mantle, reaching $120 \mathrm{~km}$ in depth below the coast, probably associated with the subducted portion of the Iberian crust beneath the Betic Internal Zones (Morales et al., 
1999; Buforn et al., 2004; Pedrera et al., 2011; RuizConstán et al., 2011). This geodynamic scenario favoured recent tectonic uplift, as revealed by the placement of Upper Miocene calcarenites at $620-450 \mathrm{~m}$ a.s.1. (Schoorl and Veldkamp, 2003), the abrupt topography, and the high incision of the fluvial network. Although geomorphological data suggest active folding north of Málaga (IGME, 2012), there is no field evidence of outcropping active faults.

\section{Conclusions}

The scarcity and low quality of outcrops including recently deformed rocks, the complex geological structure, and the lower frequency and magnitude of the seismic events along the western Betic Cordillera come to limit our knowledge of the specific active tectonic structures in this sector. However, the integrated analysis of brittle microtectonic structures together with seismicity distribution provides evidence regarding the main tectonic feactures of active sectors. The northwerstern mountain front, in the Moron de la Frontera area, is the sector with the greatest recent earthquake activity. Although seismogenic structures do not crop out at surface, low to moderate shallow epicenters reveal the presence of active reverse and transfer faults. In addition, the presence of a thick plastic Olistostromic Unit could favour site effects. Toward the Gulf of Cadiz, Pliocene and Quaternary shallow marine sedimentary rocks placed above this unit along the Atlantic coastal sector are deformed by small NW-SE to WNW-ESE normal faults and E-W to ENE-WSW reverse faults. In contrast to the Moron de la Frontera mountain front, in this sector of the Gibraltar Arc seismicity is very scarce.

Along the Internal Subbetics and Flysch units, recent NW-SE and local NE-SW trending normal to normaloblique faults are recognized, as well as ENE-WSW folds and reverse faults. Although these structures are favorably oriented for reactivation under the present-day stress setting, there are no direct relationships with earthquakes and only local evidences of Quaternary activity near Cañete la Real. The earthquakes are progressively deeper toward the south (from $40 \mathrm{~km}$ to $120 \mathrm{~km}$ beneath the Malaga coast) and bear no direct relation with structures cropping out in the Internal Zones. Intermediate seismicity is associated with the portion of the Iberian crust subducted beneath the Betic Internal Zones. This setting favours recent uplift and river incision within the Internal Zones of the Betic Cordillera.

In summary, the Western Betics is a moderate to low seismicity region in which the complex geological structure generally impedes the outcropping of deep seis- mogenic faults. Moreover, small active faults recognized at surface have complex stress and kinematic relationships with the seismogenic deep faults. Both geophysical and geological data must therefore be integrated in order to characterize the active tectonics of this region.

\section{Acknowledgements}

This study was supported by the projects TOPO-IBERIA CONSOLIDER INGENIO CSD2006-00041, CGL2008-03474-E, CGL2010-2104 and CGL 20080367 E/ BTE of the Spanish Ministry of Science and Education, as well as by Research Group RNM-148 and the project P09-RNM-5388 of the Junta de Andalucía Regional Government.

\section{References}

Aldaya, F., Campos, J., García-Dueñas, V., González-Lodeiro, F., Orozco, M. (1984): El contacto Alpujárrides/Nevado-Filábrides en la vertiente Meridional de Sierra Nevada. Implicaciones tectónicas. In: El borde mediterráneo español: evolución del orógeno bético y geodinámica de las depresiones neógenas. Departamento de Investigaciones Geológicas, C.S.I.C. and Universidad de Granada, Granada, 18-20, ISBN 00-05776-7.

Alfaro, P., Delgado, J., Sanz de Galdeano, C., Galindo-Zaldívar, J., García-Tortosa, F.J., López-Garrido, A.C., López-Casado, C., Marín, C., Gil, A., Borque, M.J. (2007): The Baza Fault: a major active extensional fault in the Central Betic Cordillera (south Spain). International Journal of Earth Sciences 97 (6), 1353-1365. doi:10.1007/s00531-007-0213-z.

Balanyá, J.C., Crespo-Blanc, A., Díaz Azpiroz, M., Expósito, I., Luján, M. (2007): Structural trend line pattern and strain partitioning around the Gibraltar Arc accretionary wedge: Insights as to the mode of orogenic arc building. Tectonics 26, TC2005. doi:10.1029/2005TC001932.

Batlló, J., Stich, D., Macià, R., Morales, J. (2010): Moment Tensor Inversion for the 5 July 1930 Montilla Earthquake (Southern Spain). Seismological Research Letters 81. doi: 10.1785/gssrl.81.5.724.

Benkhelil, J. (1976): Étude néotectonique de la terminaison occidentale des Cordilleres Bétiques (Espagne). PhD. Thesis, Université de Nice, France (unpublished).

Braga, J., Martin, J.M., Quesada, C. (2003): Patterns and average rates of late Neogene-Recent uplift of the Betic Cordillera, SE Spain. Geomorphology 50(1-3), 3-26. doi: 10.1016/S0169-555X(02)00205-2,

Buforn, E., Bezzeghoud, M., Udías, A., Pro, C. (2004): Seismic sources on the Iberia-African plate boundary and their tectonic implications. Pure and Applied Geophysics 161, 623-646. doi: 10.1007/ s00024-003-2466-1.

Buforn, E., Sanz de Galdeano, C., Udías, A. (1995): Seismotectonics of the Ibero-Maghrebian region. Tectonophysics 248, 247-261.

Buforn, E., Udías, A., Colombas, M.A. (1988): Seismicity, Source Mechanisms and Tectonics of the Azores-Gibraltar Plate Boundary. Tectonophysics 152(1-2), 89-118.

Buforn, E., Udías, A., Madariaga, R. (1991): Intermediate and deep 
earthquakes in Spain. Pure and Applied Geophysics 136, 375-393. Camacho, M.A., García-Navarro, E., Fernández, C., Alonso-Chaves, F.M. (1999): Paleoesfuerzos en las cuencas de antepaís en la parte noroccidental del arco de gibraltar (mioceno superior-actualidad). Geogaceta 25, 59-62.

Capote, R., Insua Arévalo, J. M., Martínez-Díaz, J. J., MartínGonzález, F., Tsige, M. (2002): La Sierra de Cártama: Pliegue con actividad reciente en las Béticas Occidentales (Hoya de Málaga). Geogaceta 31, 135-138.

Célérier, B. (2012): FSA: Fault and Stress Analysis software, version 38.3; http://www.pages-perso-bernard-celerier.univ-montp2.fr/software/dcmt/fsa/fsa.html

Chalouan, A., Michard, A. (2004): The Alpine Rif Belt (Morocco): a case of mountain building in a subduction-subduction- transform fault triple junction. Pure Appl. Geophys. 161, 489-519. doi: 10.1007/s00024-003-2460-7.

Crespo-Blanc, A., Campos, J. (2001): Structure and Kinematics of the South Iberian paleomargin and its relationship with the Flysch Trough units; extensional tectonics within the Gibraltar Arc foldand thrust belt (western Betics). Journal of Structural Geology 23, 1615-1630. doi: 10.1016/S0191-8141(01)00012-8.

De Vicente, G., Cloetingh, S., Muñoz-Martin, A., Olaiz, A., Stich, D., Vegas, R., Galindo-Zaldivar, J., Fernandez-Lozano, J. (2008): Inversion of moment tensor focal mechanisms for active stresses around the microcontinent Iberia: Tectonic implications. Tectonics 27(1), TC1009. doi:10.1029/2006TC002093.

Dewey, J.F., Helman, M.L., Turco, E., Hutton, D.H.W., Knott, S.D. (1989): Kinematics of the western Mediterranean. In: M. P. Coward, D. Dietrich, R.G. Park (ed), Alpine Tectonics. Geological Society Special Publication 45, 265-283.

Frohlich, C., Apperson, K.D. (1992): Earthquake Focal Mechanisms, Moment Tensors and Consistency of Seismic Activity near Plate Boundaries. Tectonics 11, 279-296.

Galindo-Zaldívar, J., Gil, A.J., Borque, M.J., González-Lodeiro, F., Jabaloy, A., Marín- Lechado, C., Ruano, P., Sanz de Galdeano, C. (2003): Active faulting in the internal zones of the central Betic Cordilleras (SE Spain). J. Geodyn. 36, 239-250. doi: 10.1007/ s00531-007-0213-z.

Galindo Zaldívar, J., González Lodeiro, F. (1988): Faulting phase differentiation by means of computer search on a grid pattern. Ann. Tectonicae 2, 90-97.

García-Castellanos, D., Fernández, M., Torne, M. (2002): Modelling the evolution of the Guadalquivir foreland basin southern Spain. Tectonics 21, 1018. doi:10.1029/2001TC001339.

García-Dueñas, V., Balanyá, J.C., Martínez Martínez, J.M. (1992): Miocene extensional detachments in the outcropping basement of the Northern Alboran Basin (Bet- ics) and their tectonic implications. Geo-Mar. Lett. 12, 88-95.

Geissler, W. H., Matias, L.,Stich, D., Carrilho, F., Jokat, W., Monna, S., Ibenbrahim, A., Mancilla, F., Gutscher, M.-A., Sallarès, V., Zitellini, N. (2010): Focal mechanisms for sub-crustal earthquakes in the Gulf of Cadiz from a dense OBS deployment. Geophysical Research Letters 37, L18309. doi: 10.1029/2010GL044289.

Gentil, P., De Justo, J.L. (1983): Terremoto de Carmona de 1504. In: Sismicidad histórica de la región de la Península Ibérica. Asociación Española de Ingeniería Sísmica. Madrid, 9-12.

Goffé, B., Michard, A., García-Dueñas, V., González-Lodeiro, F.,
Monié, P., Campos, J., Galindo-Zaldívar, J., Jabaloy, A., Martínez, J.M., Simancas, J.F. (1989): First evidence of high-pressure, lowtemperature metamorphism in the Alpujarride nappes, Betic Cordilleras (SE Spain). Eur. J. Miner. 1, 139-142.

Gómez-Pugnaire, M.T., Fernández-Soler, J.M. (1987): High pressure metamorphism in metabasites from the Betic Cordilleras (SE Spain) and its evolution during the Alpine orogeny. Contr. Miner. Petrol. 95, 231-244.

Goy, J.L., Zazo, C., Mörner, N.A., Hoyos, M., Somoza, L., Lario, J., Bardají, T., Silva, P.G., Dabrio, J.C. (1994): Pop up-like deformation of a Roman floor and liquefaction structures in SW Spain as possible paleoseismic indicators. Bulletin of the International Union for Quaternary Research (INQUA). Neotectonics Comisión 17, 42-44.

Gracia, F.J., Rodríguez-Vidal, J., Cáceres, L.M., Belluomini,G., Benavente, J., Alonso, C. (2008): Diapiric uplift of an MIS3 marine deposit in SW Spain: Implications for Late Pleistocene sea level reconstruction and palaeogeography of the Strait of Gibraltar. Quaternary Sci. Rev. 27, 2219-2231. doi: 10.1016/j.quascirev.2008.08.013

Grimison, N. L., Chen, W.P. (1986): The Azores-Gibraltar plate boundary: focal mechanisms, depths of earthquakes, and their tectonic implications, J. Geophys. Res. 91, 2029-2047.

Hancock, P.L. (1985): Brittle microtectonics: principles and practice. Journal of Structural Geology 7, 437-457.

IGME (2012): QAFI: Quaternary Active Faults Database of Iberia. Accessed March 2012, from IGME web site: http://www.igme.es/ infoigme/aplicaciones/QAFI/.

Insua Arévalo, J.M. (2008): Neotectónica y tectónica activa de la Cuenca de Málaga (Cordillera Bética Occidental). Ph.D. Thesis, Univ. Complutense de Madrid: 276 p.

Insua Arévalo, J.M., Martín González, F., Capote, R., Martínez Díaz, J.J. (2004): Análisis tectónico de los mapas de anomalía gravimétrica de la Cuenca de Málaga (Béticas Occidentales). Boletín Geológico y Minero 115(3): 521-536.

Kárník, V. (1969): Seismicity of the European Area (Vol. 1). D. Reidel Publishing Co., Dordrecht, Holland: 364 p.

Luján, M., Storti, F., Balanyá, J.C., Crespo-Blanc, A., Rossetti, F. (2003): Role of decollement material with different rheological properties in the structure of the Aljibe thrust imbricate (Flysch Trough, Gibraltar Arc): an analogue modelling approach. J. Struct. Geo. 25, 867-881. doi: 10.1016/S0191-8141(02)00087-1.

Marín-Lechado, C., Galindo-Zaldivar, J., Rodríguez-Fernández, L.R., Pedrera, A. (2006): Mountain front development by folding and crustal thickening in the Internal Zone of the Betic Cordillera-Alboran Sea Boundary. Pure Appl. Geophys. 164, 1-21. doi:10.1007/ s00024-006-0157-4.

Martínez Díaz, J.J. (2002): Stress field variation related to fault interaction in a reverse oblique-slip fault: the Alhama de Murcia fault, Betic Cordillera, Spain. Tectonophysics 356, 291-305. doi:10.1016/ S0040-1951(02)00400-6

Martínez Solares, J.M., López Arroyo, A. (2004): The great historical 1755 earthquake. Effects and damage in Spain. Journal of Seismology 8, 275-294. doi: 10.1023/B:JOSE.0000021365.94606.03

Martínez Solares, J.M., Mezcua, J. (2002): Catálogo sísmico de la península Ibérica (880 a.C. - 1900). Instituto Geográfico Nacional, Monografía 18: $253 \mathrm{p}$.

Masana, E., Martínez-Díaz, J.J., Hernández-Enrile, J.L., Santanach, P. (2004): The Alhama de Murcia fault (SE Spain), a seismogenic fault in diffuse plate boundary. Seismotectonic implications for the Ibero-Magrebian region. J. Geophys. Res. 109, 1-17. doi:10.1029/2002JB002359.

Maury, R.C., Fourcade, S., Coulon, C., El Azzouzi, M., Bellon, H., Coutelle, A., Ouabadi, A., Semroud, B., Megartsi, M., Cotton, J., 
Belanteour, O., Louni-Hacini, A., Piqué, A., Capdevilla, R., Hernández, J., Rehaoult, J.P. (2000): Post-collisional Neogene magmatism of the Mediterranean Maghreb margin: a consequence of slab breakoff. C. R. Acad. Sci. Paris 331, 159-173.

McCalpin, J.P. (1996): Paleoseismology. International Geophysics Series vol 62, Academic Press, New York.

Mezcua, J., Rueda, J. (1997): Seismological Evidence for a Delamination Process in the Lithosphere under Alboran Sea, Geophys. J. Int. 129, F1-F8.

Morales, J., Serrano, I., Jabaloy, A., Galindo-Zaldívar, J., Zhao, D., Torcal, F., Vidal, F., Gonzalez-Lodeiro, F. (1999): Active continental subduction beneath the Betic Cordillera and Alboran Sea. Geology 27, 735-738.

Morales, J., Serrano, I., Vidal, F., Torcal, F. (1997): The depth of the earthquake activity in the Central Betics (Southern Spain). Geophys. Res. Lett., 24(24), 3289-3292.

Morel, J., Meghraoui, M. (1996): Gorringe-Alboran-Tell Tectonic Zone: A Transpression System along the Africa-Eurasia Plate Boundary. Geology 24, 755-758.

Muñoz, D., Udias, A. (1988): Evaluation of damage and source parameters of the Malaga earthquake of 9 October 1680. In: W.H.K. Lee, H. Meyer and K. Shimazaki (ed), Historical Seismograms and Earthquakes of the World. Academic Press, San Diego: 208-221.

Pedrera, A., Ruiz-Constán, A., Galindo-Zaldívar, J., Chalouan, A., Sanz de Galdeano, C., Marín-Lechado, C., Ruano, P., Benmakhlouf, M. Akil, M., López-Garrido, A.C., Chabli, A., Ahmamou, M., González-Castillo, L. (2011): Is there an active subduction beneath the Gibraltar orogenic arc? constraints from Pliocene to Present-day stress field. Journal of Geodynamics 52 (2), 83-96. doi:10.1016/j. jog.2010.12.003.

Pérouse, E., Vernant, P., Chéry, J., Reilinger, R., McClusky, S. (2010): Active surface deformation and sub-lithospheric processes in the western Mediterranean constrained by numerical models. Geology, 38(9), 823-826. doi: 10.1130/G30963.1

Platt, J.P., Vissers, R.L.M. (1989): Extensional collapse of thickened continental litho- sphere: aworking hypothesis for the Alboran Sea and Gibraltar Arc. Geology 17, 540-543.

Rodríguez-Fernández, J. (1982): El Mioceno del sector central de las Cordilleras Béticas. Ph.D. Thesis, Universidad de Granada, 224 p.

Rosenbaum, G., Lister, G.S., Duboz, C. (2002): Relative motions of Africa, Iberia and Europe during Alpine orogeny. Tectonophysics 359, 117-129. doi:10.1016/S0040-1951(02)00442-0.

Ruiz-Constán, A., Galindo-Zaldívar, J., Pedrera, A., Célérier, B., Marín-Lechado C. (2011): Stress distribution at the transition from subduction to continental collision (northwestern and central Betic Cordillera). Geochem. Geophys. Geosyst. 12, Q12002. doi:10.1029/2011GC003824.

Ruiz-Constán, A., Galindo-Zaldívar, J., Pedrera, A., Sanz de Galdeano, C. (2008): Gravity anomalies and orthogonal box fold development on heterogeneous basement in the Neogene Ronda Depression Western Betic Cordillera. Journal of Geodynamics 47 (4), 210-217. doi:10.1016/j.jog.2008.09.004.

Ruiz-Constán, A., Stich, D., Galindo-Zaldívar J., Morales, J. (2009): Is the northwestern Betic Cordillera mountain front active in the context of the convergent Eurasia-Africa plate boundary? Terra Nova, 21, 352-359. doi: 10.1111/j.1365-3121.2009.00886.x

Sanz de Galdeano, C. (1990): Geologic evolution of the Betic Cordilleras in the Western Mediterranean, Miocene to the present. Tectonophysics 172, 107-119.

Sanz de Galdeano, C., Alfaro, P. (2004): Tectonic significance of the present relief of the Betic Cordillera. Geomorphology, 63, 175-190. doi:10.1016/j.geomorph.2004.04.002.
Sanz de Galdeano, C., López Casado, C., Delgado, J., Peinado, M.A. (1995): Shallow seismicity and active faults in the Betic Cordillera. A preliminary approach to seismic sources associated with specific faults. Tectonophysics 248, 293-302.

Sanz de Galdeano, C., Vera, J.A. (1992): Stratigraphic record and palaeogeographical context of the Neogene basins in the Betic Cordillera, Spain. Basin Research 4, 21-36.

Schoorl, J.M., Veldkamp, A. (2003): Late Cenozoic landscape development and its tectonic implications for the Guadalhorce valley near Álora (Southern Spain). Geomorphology 50, 43-57. doi: 10.1016/S0169-555X(02)00207-6.

Serpelloni, E., Vannucci, G., Pondrelli, S., Argnani, A., Casula, G., Anzidei, M., Baldi, P., Gasperini, P. (2007): Kinematics of the Western Africa-Eurasia plate boundary from focal mechanisms and GPS data. Geophysical Journal International, 169(3), 1180-1200. doi: 10.1111/j.1365-246X.2007.03367.x.

Serrano, F. (1979): Los foraminíferos planctónicos del Mioceno superior de la cuenca de Ronda y su comparación con los de otras áreas de la Cordilleras Béticas. Ph.D. Thesis. Universidad de Málaga, 272 p.

Serrano, I., Bohoyo, F., Galindo-Zaldívar, J., Morales, J., Zhao, D. (2002): Geophysical signatures of a basic-body rock placed in the upper crust of the External Zones of the Betic Cordillera Southern Spain. Geophysical Research Letters, 29. doi:10.1029/2001GL013487.

Silva, P.G., Goy, J.L., Zazo, C., Bardají, T., Lario, J., Somoza, L., Luque, L., González, Hernández, F.M. (2006): Neotectonic fault mapping at the Gibraltar Strait Tunnel area, Bolonia Bay (South Spain). Eng. Geol. 84, 31-47. doi: 10.1016/j.enggeo.2005.10.007.

Silva, P.G., Reicherter, K., Grützner, C., Bardají, T., Lario, J., Goy, J.L., Zazo, C., Becker-Heidmann, P. (2009): Surface and subsurface paleoseismic records at the ancient Roman city of Baelo Claudia and the Bolonia Bay area, Cádiz (south Spain). In: K. Reicherter, A.M. Michetti, P.G. Silva (ed), Paleoseismology: Historical and Prehistorical Records of Earthquake Ground Effects for Seismic Hazard Assessment. Geological Society of London Special Publication 316, p. 93-121.

Stich, D., Ammon, C.J., Morales, J. (2003): Moment tensor solutions for small and moderate earthquakes in the Ibero- Maghreb region. Journal of Geophysical Research 108 (B3). doi: 10.1029/2002JB002057.

Stich, D., Mancilla, F., Morales, J. (2005): Crust-mantle coupling in the Gulf of Cadiz (SW-Iberia). Geophysical Research Letters 32(13), 1-4. doi:10.1029/2005GL023098.

Stich, D., Martín, R., Morales, J. (2010): Moment tensor inversion for Iberia-Maghreb earthquakes 2005-2008. Tectonophysics 48, 390-398. doi:10.1016/j.tecto.2009.11.006.

Stich, D., Serpelloni, E., Mancilla, F., Morales, J. (2006): Kinematics of the Iberia- Maghreb plate contact from seismic moment tensors and GPS observations. Tectonophysics 426, 295-317. doi:10.1016/j. tecto.2006.08.004.

Zazo, C., Goy, J.L., Dabrio, C.J., Bardají, T., Hillaire-Marcel, C., Ghaleb, B., González- Delgado, J.A., Soler, V. (2003): Pleistocene raised marine terraces of the Spanish Mediterranean and Atlantic coasts: records of coastal uplift, sea-level highstands and climate changes. Marine Geology 194 (1-2), 103-133. doi: 10.1016/S00253227(02)00701-6.

Zazo, C., Silva, P.G., Goy, J.L., Hillaire-Marcel, C., Ghaleb, B., Lario, J., Bardají, T., González, A. (1999): Coastal uplift in continental collision plate boundaries: data from the Last Interglacial marine terraces of the Gibraltar Strait area (south Spain). Tectonophysics 301, 95-109. doi:10.1016/S0040-1951(98)00217-0. 